$551.8 / 924.8 /$

\author{
: \\ - убіс \\ иївський н ціон льний університет імені р с евченк, \\ вул. олодимирськ, 60, м. иїв, 01033, кр їн
}

иділено т сх р ктеризов но т кі три головні ет пи розвитку досліджень мікроскопії кв рцових зерен піщ них фр кцій: 1) кінець -поч. ст. - н копичення первинних зн нь про особливості морфометрії зерен т мікроморфології їхньої поверхні; 2) 40-70-ті роки ст. створення різном нітних візу льних, мех нічних методів дослідження морфометрії зерен кв рцу, розроблення методик кількісної оцінки їхньої обк т ності; 3) кінець $\quad$ т поч ток ст. - інтенсивний розвиток комплексних досліджень мікроскопії зерен піщ ної фр кції. креслено перспективні н прями використ ння досліджень мікроскопії зерен кв рцу піщ ної фр кції для п леогеогр фічних реконструкцій еолових процесів.

лючові слов : мікроскопія кв рцових зерен, обк т ність, мікроморфологія поверхні зерен, методи т способи досліджень, оптичний т електронний мікроскопи.

леогеогр фічні реконструкції є в жливою т скл дною проблемою четвертинної геології, геоморфології т п леогеогр фії. е виняток і проблем реконструкції поширення, інтенсивності розвитку т дин міки еолових процесів, ет пів формув ння т віку реліктових кумулятивних еолових форм рельєфу - м терикових дюн. собливо це стосується ідентифік ції кумулятивних піщ них форм рельєфу, що не м ють вир зної “еоловоі” морфометрії т х р ктерної (косої) для еолових форм текстури піщ них відкл дів. ослідження у різних кр їн х, зокрем ольщі, p нції, імеччині, веції, еликій рит нії, ідерл нд $\mathrm{x}$, зр їлі, понії, , з свідчили, що одним з критеріїв п леогеогр фічних реконструкцій можуть слугув ти результ ти дослідження мікроскопії зерен кв рцу певних піщ них фр кцій. роведення т ких досліджень $є$ в жливими для вирішення пит ння генезису кумулятивних реліктових піщ них форм кр їнського олісся, що дискутують уже пон д століття.

ш мет - виділення т н ліз основних історичних ет пів розвитку досліджень мікроскопії кв рцових зерен піщ них фр кцій у кр їн х постр дянського простору т інших держ в х вропи, т кож зіст влення різних методик досліджень для їхнього використ ння в п леогеогр фічних реконструкціях еолових процесів.

н ліз літер турних джерел [2, 3, 5-11, 14-17, 26, 28 т ін.] т результ ти вл сних досліджень д ли змогу виділити кільк вихідних положень, н яких грунтуються дослідження мікроскопії кв рцових зерен піщ них фр кцій.

1. ервинні зерн теригенних відкл дів, у тому числі й кв рцу, усп дкув ли риси мінер лів корінних порід т м ють х р ктерні для цих мінер лів вл стивості.

2. ерно кв рцу є індик тором п леогеогр фічних умов формув ння відкл дів, що визн чене його вл стивостями як мінер лу. е зумовлено, н с мперед, хімічним скл -

убіс ., 2010 
дом т будовою крист лічної гр тки, що визн ч є форму крист л, його твердість, т кож стійкість кв рцу до різном нітних процесів звітрюв ння, мех нічного руйнув ння тощо.

3. роцес зміни морфології зерен кв рцу відбув ється поступово т д є інформ цію про середовище, спосіб тр нспортув ння і седимент цію відкл дів.

4. оверхня зерен кв рцу дост тньо довго зберіг є озн ки (сліди) екзогенних впливів, що д є змогу відн йти риси кількох середовищ перебув ння, тр нспортув ння т кумуляції зерен, що є н дзвич йно в гомим у р зі п леогеогр фічних реконструкцій.

т новлення мікроскопічного н лізу зерен кв рцу м $є$ більше ніж столітню історію. е н прикінці ст. н уковці, досліджуючи четвертинні відкл ди, звернули ув гу н різний ступінь обк т ності піщ них зерен. окрем, відомий укр їнський учений, дослідник, к демік - утковський один із перших з зн чив про можливість генетичної кл сифік ції пісків н підст ві мінер логічного скл ду відкл дів, ступеня обк т ності зерен кв рцу т їхнього блиску [4]. допомогою цих головних критеріїв він розробив генетичну кл сифік цію піщ них відкл дів олісся, виділивши три типи піску: передльодовиковий, льодовиковий і люві льний [13]. дн к ідеї генетичної кл сифік ції пісків н підст ві відмінностей морфології зерен піщ них фр кцій не м ли под льшого широкого розвитку в укр їнській геоморфології т п леогеогр фії. годом відомий фр нцузький геолог ндре йє, вивч ючи четвертинні відкл ди вропи, з стосув в метод мікроскопії зерен кв рцу для визн чення генезису піщ них відкл дів. р ці . йє $[5,19]$ д ли поштовх для розвитку досліджень мікроскопії зерен кв рцу, що н були зн чних м сшт бів у різних кр їн х вропи т

н ліз укр їнських т з рубіжних літер турних джерел, н укової інформ ції д в змогу виділити три головні ет пи ст новлення т розвитку досліджень мікроскопії зерен кв рцу піщ них фр кцій:

перший ет $n$ - кінець -поч ток ст. - н копичення первинних зн нь про особливості морфометрії зерен т мікроморфології їхньої поверхні. ерші спроби генетичної кл сифік ції піску н підст ві різного літологічного скл ду піщ них відкл дів 3 ур хув нням візу льної оцінки обк т ності зерен кв рцу;

другий ет $n-40-70$-ті роки ст. творення різном нітних візу льних, мех нічних методів дослідження морфометрії зерен кв рцу, розроблення методик кількісної оцінки обк т ності зерен т перші спроби п леогеогр фічної інтерпрет ції отрим них результ тів;

третій ет $n$ - кінець -поч ток ст. - інтенсивний розвиток комплексних досліджень мікроскопії зерен піщ ної фр кції з кордоном. ивчення особливостей мікроморфології поверхонь кв рцових зерен в електронному мікроскопі т їхня генетичн інтерпрет ція. ідновлення досліджень мікроскопії кв рцових зерен в кр їні.

сновоположником досліджень мікроскопії зерен кв рцу вв ж ють . йє. 1942 р. він з пропонув в методику досліджень, яку згодом н зв в мікроскопія [19]. я методик грунтув л ся н вивченні ступеня з округлення т х p ктеру поверхні піщ них зерен (н йч стіше кв рцових) у бінокулярному мікроскопі. ослідник виділив чотири головні групи зерен [19]:

1) необроблені (non uses);

2) оброблені блискучі (emousses luisants);

3) округлі м тові (ronds mats propres);

4) округлені м тові з бруднені (rond mats sale). 
н ступних пр цях . йє виділив тільки три головні групи, з зн чивши про існув ння ще двох типів зерен кв рцу - зерн зі слід ми кременистого т з лізистого цементу т зерн з кр пковою поверхнею, що сформув лися вн слідок хімічної кор зії.

йє, н лізуючи генезис пісків території колишнього дянського оюзу [5], окрім зерен трьох основних і двох дод ткових груп, окремо підр хув в зерн групи м тових обк т них з подряпин ми. же з досліджень . йє зрозуміло, що є й інші типи зерен, які не н леж ть до жодної з основних виділених ним груп. 1963 р. К. ліньск уттке, пр цюючи $з$ методикою . Йє, увел дод ткову групу зерен кв рцу - посередню (між обробленими блискучими т округлими м товими) [18], 1973 р. . одзік дод в ще одну - тріснутих [20].

3 кордонних дослідженнях ступінь обк т ності зерен кв рцу оцінюють методом . p мбейн [22]. ослідник розробив десяти ступеневу м трицю оцінки з округлення зерен кв рцу. ев'ять перших зр зків м триці відобр ж ють різні ступені обк т ності зерен, ост нній - десятий - різновиди тріснутих зерен. чені порівнюють ступінь 3 округлення ре льного зерн кв рцу з ет лонними зр зК ми м триці й визн ч ють його обк т ність т з писують їі десяткову величину відповідно до номер зр зK .

кр їн х постр дянського простору візу льну оцінку обк т ності зерен кв рцу піщ них фр кцій виконують 3 п'ятиб льною шк лою (від 0 до 4) з використ нням тр ф рету, що рекомендов ний . ухіним (1961). доповненому вид нні книги “ сновы литологии. чение об ос дочных пород х" . ухін (1969) для візу льної оцінки зерен піщ ної фр кції дод тково з пропонов но ст нд ртну шк лу контурів для сферичних т видовжених зерен [10].

рудомісткими т скл дними в оцінці зерен є методи визн чення коефіцієнт видовження зерен з . інгом [9, 17], з м льовув ння контурів т вимірюв ння лінійкою форм зерен у мікроскопі . обсон , . істеліус [9], з стосув ння лінійокн с док . т нов й . іскіжев [8], мікрофотогр фув ння зерен кв рцу . ор вського $[24,25]$ т зіст влення фотогр фій зі зр зк ми м триці. р мбейн . хнє використ ння д в ло точніші результ ти, одн к $з$ тр ти ч су і пр ці були н дто великими для широкого з стосув ння в п леогеогр фічних дослідженнях.

60-70-х рок х ст. великої популярності н бул груп методів мех нічного визн чення ступеня обк т ності зерен з допомогою прил дів, проте підходи до побудови цих прил дів, принципу роботи т вибору піщ них фр кцій були різними.

ольщі т інших кр їн х хідної вропи використовув ли метод гр ніформометрії . риговського [23]. допомогою спеці льно розробленого прил ду (гр ніформометр ) визн ч ли кількість зерен різного ступеня обк т ності. уть методу поляг л в підр хунку кількості зерен певної фр кції, що зменшуються в р зі зміни кут п діння поверхні н $2^{\circ}$ [23]. н лізув ли зерн кв рцу фр кцій 0,5-0,8 т 0,8-1,0 мм. . риговський виділив три головні типи зерен кв рцу: $\gamma-3$ високою обробкою, $\beta-3$ посередньою обробкою; $\alpha$ - без обробки. ерн типу $\gamma$ скочуються 3 н хилу поверхні пон д $8^{\circ} ; \beta-3$ н хилу пон д $8^{\circ}$, одн к до $16^{\circ} ; \alpha-$ пон д $16^{\circ}$. результ т ми досліджень будують гістогр ми обробки зерен. хній н ліз д в в змогу виділяти чотири типи гістогр м із різним ступенем обробки зерен кв рцу - високий, низький, плоский, комбінов ний $[23,17]$, що свідчили про різний генезис відкл дів.

одібний кількісний метод оцінки обк т ності зерен, зокрем і кв рцу, у 70-ті роки

ст. 3 пропонов ний сесоюзним н уково-дослідним геологічним інститутом, де поділ ч стинок 3 морфологією виконув ли н вібросеп р торі. ля н лізу використо- 
вув ли фр кцію 0,315-0,25 мм, основою поділу був рух ч стинок уверх по ввігнутій шорсткій поверхні під впливом вібр ції до моменту, коли сил зчеплення між ч стинкою і поверхнею не ст не меншою від сили скочення $[7,10]$. ей метод д в змогу отрим ти велику кількість д них, виконув ти н літичну оцінку мінер льного скл ду піщ ної фр кції, ступеня обк т ності різних мінер лів.

етоди мех нічної оцінки обробки зерен м ють свої перев ги. они допом г ють отрим ти велику кількість д них, є порівняно простими й позб влені суб'єктивізму, що неминуче в р зі візу льної оцінки обк т ності зерен, т не з леж ть від професіон лізму дослідник . уттевим недоліком їхнього використ ння є відсутність інформ ції про мікроморфологію поверхні зерен кв рцу, що суттєво в р зі п леогеогр фічних реконструкцій, зокрем , еолових процесів.

пр цях . турін [3], . ухін [9, 10], . іч гов [14] т інші відомі дослідники використовують метод оцінки морфології зерен як один з головних для визн чення генезису четвертинних відкл дів. езв ж ючи н це, він не н був широкого з стосовув ння в дослідженнях четвертинних відкл дів у кр їн х постр дянського простору.

н чним кроком уперед т ренес нсом у дослідженнях мікроскопії кв рцових зерен у осії ст ли пр ці . д рцев , . імірєвої, . рєнової, викон ні під керівництвом відомого російського вченого, з відув ч бор торії еволюційної геогр фії нституту геогр фії , д-р геогр. н ук, проф. . еличк . цих пр цях з стосов но комплексну оцінку мікроскопії зерен кв рцу, що грунтується н вивченні форми зерен, типу його поверхні т мікрорельєфу. . імірєв [12] використовує п'ятиб льну шк лу . ухін, чотириступеневу систему оцінки поверхні (глянцев, чвертьм тов, н півм тов , м тов ) т вивчення мікрорельєфу зерен кв рцу в електронному мікроскопі, що широко з стосовують у з рубіжних дослідженнях, зокрем, , еликій рит нії, горщині, ольщі т інших кр їн х. ей метод є порівняно новим у вивченні мікроморфології поверхонь зерен кв рцу, проте вже розроблено дет льні ді гностичні озн ки мікрорельєфу поверхні зерен кв рцу, що свідч ть про різні середовищ перебув ння зерен т їхню дин міку. ослідженням мікроскопії кв рцових зерен, зокрем мікрорельєфу поверхні, в електронному мікроскопі т його генетичній інтерпрет ції, присвячені пр ці . лєксєєвої $[1,2]$, викон ні н к федрі геоморфології т п леогеогр фії геогр фічного ф культету осковського держ вного університету імені . омоносов .

йбільше прид тним, н н шу думку, для п леогеогр фічної інтерпрет ції д них т реконструкції еолових процесів є метод оцінки ступеня обк т ності зерен кв рцу т х р ктеру мікроморфології їхньої поверхні, з пропонов ний . ицельск - овгялло т оронко [27]. ін грунтується н метод х оцінки ступеня обк т ності . р мбейн [22], м товості т блиску поверхні . йє [19], що пізніше модифіков ний . одзіком [20]. ля досліджень використовують зерн кв рцу фр кцій 0,5-0,8 т 0,8-1,0 мм. г лом дослідники виділяють сім груп і д ють їм обгрунтов ну п леогеогр фічну інтерпрет цію $[27,28]$.

о першої групи н леж ть зерн кв рцу, що не м ють жодних слідів обробки, 3 добре вир женими гр нями (NU; 0,1-0,2 ступені обробки 3 . р мбейном). хне утворення н йч стіше пов'яз не з фізичним звітрюв нням $\mathrm{T}$ х р ктерне для першої ф зи літогенезу - гіпергенезу. елик кількість т ких зерен тр пляється в морен $\mathrm{x}[1,2$, $12,17,20,28]$. роте пит ння їхньої н явності в морені $є$ досить дискусійним. дні вче- 
ні їхнє н дходження пов'язують з льодовиковою екз р цією, інші - із вивільненням 3 породи під ч с руху льодовик .

о другої групи з числено м тові округлі зерн $(\mathrm{RM} ; 3$. м товою поверхнею, шо м йже не пропуск ють відбитого світл в оптичному мікроскопі. кі зерн кв рцу свідч ть про інтенсивні еолові процеси т трив лу еолову обробку зерен $[12,17,19,20,27]$. к виплив є з досліджень . ицєльск - овгялло $[17,26]$, . ицєльск - овгялло, . оронко [27, 28], зерн другої групи іноді тр пляються у флювіоперигляці льних відкл д х і $є$ н слідком попередніх еолових процесів. я ж груп об’єднує т кож зерн з неглибоко м тов ною поверхнею $[17,27]$, що м ють кременисту шк р лупу.

о третьої групи н леж ть з округлені блискучі зерн (EL; 3 . р мбейном групи $\geq 0,7)$. они м ють високий ступінь 3 округлення т вигл джену блискучу поверхню. кі зерн формуються у високоенергетичному флюві льному середовищі [12, 17, 19, 25, 27]. цій групі т кож виділяють з округлені зерн кв рцу з неглибоко м тов ною поверхнею, що х р ктерні для флюві льного середовищ, у якому водноч с відбув ються і процеси хімічного звітрюв ння н поверхні зерн кв рцу [27].

йбільш різном нітною є четверт груn , що охоплює посередні зерн (EM/RM; 3 р мбейном 0,3-0,4 групи обробки). о неї з числюють м тові кв рцові зерн 3 незн чним ступенем з округлення т блискучі бо “свіжі" зерн з м товою поверхнею н гр нях. лискучі, як звич йно, свідч ть про ініці льні (порівняно короткотрив лі) еолові процеси $[17,27]$.

'ят груn об'єднує блискучі, сл бко з округлені зерн (RM/EM; 0,3-0,6 групи з p мбейном), що свідч ть про короткоч сне перебув ння зерен кв рцу у високоенергетичному флюві льному середовищі [17, 19, 20, 27].

о шостої групи н леж ть тріснуті зерн (C; тріснут груп 3 . р мбейном). ю групу зерен можн тр ктув ти по-різному. одного боку, з числюв ти зерн цієї групи до певного кл су, що з зн чені вище, з іншого, - виділяти як с мостійну групу.

о сьомої групи з числено інші зерн кв рцу з мікроморфологією поверхні, що не н леж ть до жодної з попередніх груп т н йч стіше формуються під впливом інтенсивних процесів морозного бо хімічного звітрюв ння без вир зних слідів тр нспортув ння [27].

оєдн ння досліджень мікроскопії кв рцових зерен з методикою . ицєльскоїовгялло т . оронко (1998) з вивченням їхньої поверхні в електронному мікроскопі $\epsilon$ н йліпшим для реконструкції еолових процесів. рикл дом може слугув ти скл дність розрізнення в оптичному мікроскопі м тової поверхні зерен кв рцу, що створені еоловими процес ми т кременистою шк р лупою $[17,27]$, що дуже легко вирізняються в електронному мікроскопі.

стосув ння комплексних досліджень мікроскопії кв рцових зерен р зом з іншими метод ми досліджень четвертинних відкл дів д сть змогу виділити основні перспективні н прями вивчення т реконструкції еолових процесів, зокрем, території кp їнського олісся. о основних з числимо т кі:

відтворення інтенсивності розвитку еолових процесів для різних $n$ леогеогр фічних ет пів плейстоцену $m$ голоцену н підст ві дослідження мікроскопії зерен кв рцу піщ ної фр кції опорних стр тигр фічних розрізів четвертинних відкл дів;

визн чення ет пів формув ння реліктових кумулятивних еолових форм - м терикових дюн. p к викопних грунтів у реліктових дюн х, н прикл д лого олісся, свідчить про відсутність трив лих перерв у формув нні цих дюн т їхній ст біліз ції. 
т пність формув ння т ких дюн можн відтворити 3 мікроскопією кв рцових зерен, особливостями текстури відкл дів стр тигр фічних розрізів і д тув ннями піщ них відкл дів різними метод ми;

відтворення трив лості $m$ інтенсивності еолових процесів у різні ет пи формув ння реліктових дюн. ослідження мікроскопії кв рцових зерен у вертик льному стр тигр фічному розрізі кумулятивних еолових форм, що чітко ідентифіков ні 3 морфологією, д ють змогу визн чити трив лість т інтенсивність еолових процесів у різні ет пи формув ння реліктових дюн;

окреслення ймовірних джерел н дходження піш, ного м тері лу. орівняльний н ліз мікроскопії кв рцових зерен у поєдн нні із вивченням мінер логічного скл ду відкл дів реліктових еолових кумулятивних форм т інших генетичних типів відкл дів д сть змогу окреслити ймовірні джерел н дходження (моренні, люві льні, флювіогляці льні відкл ди тощо) піщ ного м тері лу, з яких сформув лися реліктові дюни.

тже, в жливою проблемою сьогодення в дослідженні еолового морфогенезу є розробк комплексного пок зник еоліз ції піщ них відкл дів з ур хув нням мікроскопії кв рцових зерен т інших літологічних критеріїв ідентифік ції реліктових піщ них кумулятивних еолових форм, що не м ють х р ктерної “еолової” морфометрії т , відповідно, можуть м ти різний генезис. о них з числено т кож покривні еолові піски, що не утворють вир зних кумулятивних форм [21] т ч сто повторюють форму рельєфу, н якій вони з ляг ють.

1. лексеев . . икроморфология поверхности кв рцевых зерен к к индик тор условий ледникового ос дкообр зов ния (н примере 6 ссейн р. ротвы) // итология и полезные ископ емые. 2005. №5. . 485-494.

2. лексеев . . еремещение и ди генетическое преобр зов ние кв рцевых зерен и их п леогеогр фическ я интерпрет ция // естн. оск. ун-т . ер. 5. еогр фия. 2003. №. 4. . 40-47.

3. турин . . етрогр фический н лиз геологического прошлого по терригенным компонент м. $\quad$; $: \therefore$ зд-во , 1947. 338 с.

4. ортник . ., убіс . . деї еолового морфогенезу в пр цях . . утковського // із. геогр фія т геоморфологія. 2009. ип. 55. . 87-99.

5. йе. орфоскопическое изучение некоторых песков и рыхлых песч ников н территории оветского оюз // овейш я тектоник, новейшие отложения и человек. $\quad . \quad$ зд-во оск. унт , 1969. б. 1. . 20-28.

6. огвиненко . . сновы методики исследов ния ос дочных пород. рьков: зд-во рьков. ун-т , 1962. 207c.

7. етодическое руководство по изучению и геологической съемке четвертичных отложений / г дж нян . ., орисов . ., р йцев . . и др. .: едр , 1987. 308 с.

8. етоды изучения ос дочных пород/ од. ред. . . .2. $564 \mathrm{c}$.

9. ухин . . сновы литологии. чение об ос дочных пород х..$\therefore$ остоптехизд т, 1961.779 с.

10. ухин . . сновы литологии. чение об ос дочных пород х: 2-е изд. $\quad . \quad$ едр, 1969.703 с.

11. идоренко . . оловые песч ные отложения и их ди гностические призн ки // етоды изучения ос дочных пород. 1957. . 2. . 452-467.

12. имирев . . ин мик экзогенных процессов в ледниковых и перигляци льных зон х среднего и позднего плейстоцен центр усской р внины (н основе н лиз морфоскопии и морфометрии песч ных кв рцевых зерен: втореф. дисс. ... к нд. геогр. н ук. ., 1989. 17 с.

13. утковський . . риродня р йониз ція кр їни. енетичн кл сифік ція і розподіл фізикогеогр фічних кр євидів кр їни н підст ві геологічної їх еволюції. ., 1922. 79 с. 
14. ич гов . . пыт определения генезис рыхлых отложений по морфологии песч ных зерен // зв. ер. геогр. 1959. № 1. . . 108-114.

15. нцер . . черки учения о генетических тип х континент льных ос дочных обр зов ний. $\therefore$ ук, $1966.239 \mathrm{c}$.

16. $\quad$ в нов . . есч ные породы и методы их изучения. $\quad \therefore \quad$ едр , 1969. 247 с.

17. Badania cech teksturalnych osadów szwartorzędowych i wybrane metody oznaczania ich wieku / Pod red. E. Mycielska-Dowgiałło i J. Rutkowskiego. Warszawa, 2007. 279 s.

18. Balińska-Wuttke $K$. Badania morfometryczne ziarn piasków plejstoceńskich w dorzeczu Rawki // Buil. Geologicznij UM. 1963. . 3. S. 3-67.

19. Cailleux A. Les oction eoliennes periglaciaires en Europe // Mem. Soc. Geol. France. 1942. Vol. 41.1. P. $1-176$.

20. Godzik J. Wybrane metody analizy ksztaltu ziarn piasków dla celów paleogeograficznych i stratygraficznych // Badania osadów czwartorzedowych. Wybrane metody i interpretacja wyników. Warszawa, 1995. S. 115-132.

21. Godzik J. Struktury sedymentacyjne w eolicznych piaskach pokrywowych w Polsce // Struktury sedymentacyjne i postsedymentacyjne w osadach czwartorzędowych i ich wartość interpretacyjna / Pod red. E. Mycielska-Dowgiałło. Warszawa, 1998. $279 \mathrm{~s}$.

22. Krumbein W.C. Measurement and geological significance of shape and roundness of sedimentary particles // Sed. Petrolog. 1941. Vol. 11. P. 64-72.

23. Krygowski . Graniformametria mechaniczna - zastosowanie, teoria // Prace Komitetu Geogr.-Geol. 1964. T. 2(4). S. 1-112.

24. Morawski J. Metoda badania morfologii ziarn piasku za pomoca powiekszainika fotograficznego // Lublin. Ann. UMCS. 1955. . 10. S. 199-216.

25. Morawski J., Mycielska-Dowgiałto E. Procesy morfodynamiczne w zlewni górnej Amazonki w świetle uze bienia powierchni ziarn kwarcowych w mikroskopie elektronowym // Prace i studia geograficzne. 1988. T. 9. S. 141-173.

26. Mycielska-Dowgiatto E. Wstep do sedymentologii. Kielce: Wyzsza szkola pedagogiczna, 1980. $177 \mathrm{~s}$.

27. Mycielska-Dowgiałto E., Woronko B. Analiza obtoczenia i zmatowienia powierzchni ziarn kwarcowych frakcji piaszczystej i jej wartość interpretacyjna // Przeg. Geol. 1998. T. 46. N 12. S. 1275-1281.

28. Mycielska-Dowgiatto E., Woronko B. The degree of aeolization of Quaternary deposits in Poland as a tool for stratigraphic interpretation // Sedimentary Geology. 2004. Vol. 168. P. 149-163.

\title{
MICROSCOPY STUDY OF QUARTZ GRAINS: THE HISTORY OF DEVELOPMENT AND PERSPECTIVE OF USE IN PALEOGEOGRAPHIC RECONSTRUCTIONS OF EOLIAN PROCESSES
}

\author{
L. Dubis \\ Taras Shevchenko National University of Kyiv, \\ Volodymyrska St., 60, UA-01033 Kyiv, Ukraine
}

In the article was determined and characterized three main stages of microscopy researches of quartz grains of sandy fraction. First - end of XIX-beginning of XX centuries - accumulation of primary knowledge about grain morphometry and surface micromorphology features. Second stage - 4070-th years of XX century - creation the different visual, mechanical research methods of quartz grains morphometry, development of quantitative estimation methods. Third stage - end of XX-beginning of XXI centuries - intensive development of microscopy grains of sandy fraction complex researches. A perspective direction to use the microscopy of quartz grains of sand fraction for paleogeographic reconstructions of eolian processes was outlined.

Key words: microscopy of quartz grains, roundness, micromorphology of, grain surface, methods of research, optical and electronic microscopes. 


\title{
- убис
}

\author{
иевский н цион льный университет имени р с евченко, \\ ул. л димирск я, 60, г. иев, 01033, кр ин
}

ыделено и ох р ктеризов но т кие три основные эт пы р звития исследов ний микроскопии кв рцевых зерен песч ных фр кций: 1) конец $\quad$-н ч ло ст. - н копление первичных зн ний об особенностях морфометрии зерен и микроморфологии их поверхности; 2) 40-70-е год ст. - созд ние р знообр зных визу льных, мех нических методов исследов ния морфометрии зерен кв рц , р зр ботк методик количественной оценки их ок т нности; 3) конец

н ч ло ст. - интенсивное р звитие комплексных исследов ний микроскопии зерен песч ной фр кции. черчено перспективные н пр вления использов ния исследов ний микроскопии зерен кв рц песч ной фр кции для п леогеогр фических реконструкций эоловых процессов.

лючевые слов : микроскопия кв рцевых зерен, ок т нность, микроморфология поверхности зерен, методы и способы исследов ний, оптический и электронный микроскопы.

т ття н дійшл до редколегії 19.09.2009

рийнят до друку 20.12.2009 